\title{
Introduction: Mind State and History in Britain 1960-2010
}

\author{
George Ikkos and Nick Bouras
}

'The need to lend a voice to suffering is a condition of all truth.'

T. W. Adorno ${ }^{1}$

At the end of the Second World War in 1945, Britain emerged victorious, with the largest industrial base in Europe and its empire intact; but it was also in debt to the United States, which led to continuing food rationing and a decade of austerity. Nevertheless, by the end of the 1950s the economy had recovered, setting in motion a doubling of gross domestic product (GDP) between 1950 and 1975, a feat not matched between 1975 and 2000. This despite, or perhaps because, the fact that the empire began to recede from the late 1940 s. By the mid-1960s, it had been lost for good.

The period 1960-2010 coincides with major changes in UK politics, the economy, society and health care. Legislation such as the Abortion and Sexual Relations Acts in 1967, the Race Relations Act 1968 and the Equal Pay Act 1970 illustrates the direction of reform. Since 1979, the successive electoral triumphs of Margaret Thatcher (and the acceptance by New Labour of the general thrust of her policies - particularly in health care) fundamentally changed the nation's orientation but did not reverse the liberalising trends. For example, with respect to diversity, positive change has advanced regardless, even if it is still short of natural justice.

It was also a period of major transformation in the international operating environment. Events such as the Oil Crisis of 1973, the collapse of the Soviet Union in 1989 and the 'War on Terror' since 1991 have weighed heavily on internal matters. For example, while the communist Soviet Union had continued to give the impression of a living European ideological alternative to Western liberal democracies, dominant centre-right and centreleft UK politicians had been reluctant to allow inequality and social exclusion to flourish. Later market-oriented libertarians have had no such qualms. Even a senior New Labour figure achieved notoriety by proclaiming himself as 'intensely relaxed about people getting filthy rich', adding 'as long as they pay their taxes'.

During this period, the UK has moved from a narrow post-war social conservativism, through liberalism and social welfare, towards libertarianism, free market fundamentalism and trade globalisation. However, at a time of significant growth in inflation-adjusted GDP, these changes, though questioning of the role of the state, did not prevent the proportion of GDP expenditure on health rising from 3.1 per cent in 1960 to 7.5 per cent in 2010 (see also Chapter 11). Yet, by contemporary European standards, it should have been more.

Among the biggest transformations have been those of deinstitutionalisation and community care in psychiatry and mental health. Challenged by the marketisation of the National Health Service (NHS), the early community care reformers might hardly recognise 
the current landscape. Evolving technology has also had an enormous impact, though less so in psychopharmacology than had been hoped. Since 1990, the explosion in big data and new social media has brought us to a radically different phase, perhaps a fourth industrial revolution dominated by artificial intelligence. In Greek, 'meta' means 'after' and we have argued that we have now entered a new era of 'meta-community' psychiatry and mental health care. ${ }^{2}$ This, coupled with the shock of the financial crisis of 2008 , makes it timely to look back to the half-century 1960-2010 and reflect on changes during those decades.

The motivating questions behind this volume are, what have citizens' attitudes towards mental ill health been? How have those with mental ill health and their families or other informal and formal carers fared? And what has changed for mental health professionals? In exploring these questions, we have tried to avoid the pitfall of restricting ourselves to themes of deinstitutionalisation and community care and to shine the light more broadly. ${ }^{3}$ Our intentions have been to bear witness, inform and stimulate curiosity and research but not be exhaustive in detail.

As editors, we have been determined to steer a course between self-sufficiency in each chapter and the structural integrity of the whole volume. Many of the contributors have been protagonists of psychiatry and mental health care, some experts by experience. Their chapters will reflect these experiences and personal opinions. We believe these add depth. However, as well as addressing a range of more narrowly defined facets of psychiatry and mental health services, the volume is also enriched by historical, sociological and political contributions. As ideological considerations have had and are likely to continue to have influence, complementary or discordant perspectives should help refine debate and advance policy and practice. ${ }^{4}$ Though each chapter may be read on its own, we believe that those who read the volume as a whole will benefit most. We have thought carefully about whether the title of the book should refer to British or UK history. There are a handful of references to Northern Ireland but not to clinical services. Therefore, we decided to refer only to Britain in the title.

Readers will find that some ideas, events, institutions, policies and so on recur through different chapters. This is because of the cardinal position of certain constellations during this period which merit repeated illumination. As Walter Benjamin observed:

One only knows a spot once one has experienced it in as many dimensions as possible. You must have approached a place from all four cardinal points if you want to take it in, and what's more, you also have to have left it from all these points. Otherwise it will quite unexpectedly cross your path three or four times before you are prepared to discover it. ${ }^{5}$

\section{Notes}

1. T. W. Adorno, Negative Dialectics, trans E. B. Ashton. London: Routledge, 1973, p. 17.

2. N. Bouras, G. Ikkos and T. Craig, From community to meta-community mental health care. International Journal of Environmental Research and Public Health (2018) 15: 806, https://doi.org/10.3390/ijerph15040806

3. J. Turner, R. Hayward, K. Angel et al., The history of mental health services in modern England: Practitioner memories and the direction of future research. Medical History (2015) 59: 599-624, 600.

4. N. Bouras and G. Ikkos, Ideology, psychiatric practice and professionalism. Psychiatriki (2013) 24(1): 17-27.

5. W. Benjamin, Moscow Diary, trans R. Sieburth. Cambridge, MA: Harvard University Press, 1986, p. 25. 